\section{Isotopic Tracers}

A Theoretical and Practical Manual for Biological Students and Research Workers. By G. E. Francis, W. Mulligan and Prof. A. Wormall. Pp. xvi +306 . (London: University of London, The Athlone Press, 1954. Distributed by Constable and Co., Ltd.) $37 s .6 d$. net.

THE authors of this book have experience both of teaching and using isotopic tracer techniques; they write on both theoretical and practical aspects of the subject. They describe the preparation, properties and measurements of radioactive and stable tracers and their compounds. The sections on autoradiography, health hazards and syntheses are excellent, and sound practical details are given for a variety of experiments which are biased in favour of biological investigations. Experimental data are frequently given in the form of useful tables and graphs. References are of ten made to original literature and other texts.

The book might be criticized on a number of points. The implications of the statistical interpretation of disintegration-rates should have been discussed in the text and not mainly in the appendix. The use of sodium hydroxide for the purification of deuterium oxide seems unwise; furthermore, the use of chromic acid is suggested instead of chromium trioxide. Their first definition of specific activity in terms of the ratio of numbers of atoms is not in general use; and even in their own experimental section it does lead to an anomalous situation (experiment 2).

In spite of these criticisms, the book can be recommended to biologists who wish to survey, or use, tracer techniques: even for biological students, however, more information on results would be desirable. Other research workers and teachers will find the book useful as a concise summary of the subject.

S. J. THOMSON

\section{Rome Beyond the Imperial Frontiers}

By Sir Mortimer Wheeler. Pp. xii $+192+38$ plates. (London: G. Bell and Sons, Ltd., 1954.) 25s. net.

$\mathrm{T}$ this valuable work Sir Mortimer Wheeler presents 1 a critical discussion of the extent of the diffusion of Roman objects, made in Italy or within the Empire, and draws conclusions on the results of the penetration of Roman influenoes during the first three centuries of the Christian era. The evidence is dealt with under the headings of Free Germany, Africa, and India and the Far East in this order. In the case of Europe this evidence is both literary and archæological, and in presenting a masterly summary of this aspect Sir Mortimer draws largely on the recent extensive work of Eggers, of Broholm and others. His own conclusion is that Roman trade in Europe became important in the first century, when the spread was from Italy by way of the Danube to the Baltic and to Bohemia. About the end of the second century objects made in Groul and the Rhineland were carried to the north-east and east. Later there was an extension from South Russia to Byzantium.

After a brief section on recent work in the Fezzan and the Hoggar in the Sahara, Sir Mortimer deals with the important discoveries in India, at Arikamedu, Taxila and Begram, with which he has been associated. His general conclusion is that the most important impact of the Western on the Eastern world occurred in the early centuries of the Christian era, when it produced a significant change in Buddhist art.

The plates in this book are most carefully chosen. The evidence is assembled with the author's usual skill. A minor suggestion is that the concluding "Retrospect" emphasizes five imports, and the general reader might well read this section first.

\section{John William Bews}

A Memoir. By George W. Ga.le. Pp. 140. (Pietermaritzburg : University of Natal Press, 1954.) n.p. DROF. J. W. BEWS, who died in 1938 at the early age of fifty-three, was for many years a leading figure in botanical circles in South Africa and was one of the foremost plant ecologists of his day. A well-written account, delayed by the War and other causes, of his life and work has now appeared. The author, who is dean of the Faculty of Medicine in the University of Natal, was one of Bews's early postgraduate students in botany at Pietermaritzburg. It was General Smuts, with whom Bews was on friendly terms, and with whom he shared a common interest in the grasses and grasslands of southern Africa, who first suggested that there should be some permanent record of Bews's life and work.

The book gives a detailed and interesting account of Bews's life, including his boyhood in the Orkneys, for he was the son of an Orkney farmer, his student days at Edinburgh, where he graduated in both arts and science, and his working-life in South Africa. In addition to his ability as an ecologist and as a teacher, Bews later proved himself to be an able university administrator. He was, in fact, one of the founders of university education in Natal. Many of his students now hold important botanical posts in South Africa. The writer gives a descriptive account of Bews's published work, of which there were seven books, including works on human ecology.

\section{Squirrels}

By Monica Shorten. (New Naturalist Special Volume.) Pp. xii $+212+15$ plates. (London: William Collins, Sons and Co., Ltd., 1954.) 15s. net.

7 HIS admirable book combines the scientific approach with clear and attractive writing. It will be news to many of the author's readers that the supposed hibernation of the red squirrel is a myth. The animal cannot live for more than a few days without food, and has been watched in full activity in Switzerland when the thermometer stood at $-15^{\circ} \mathrm{C}$. The author, writing first about the red squirrel, tells us many interesting facts about it. The present race in Britain (like the capercaillie) has been introduced at various times, although the native stock may have survived in the counties of Sutherland and Inverness. Harvie Brown recorded a red squirrel on Beinn Bhrotain, a high hill in Mar $3,829 \mathrm{ft}$. above sea-level, at least nine miles from the nearest tree. This looks like migration between the Scots fir forests of Mar in Aberdeenshire and Glen Feshie in Inverness-shire. In her notes on the red squirrel's enemies (p. 36), the author does not mention the golden eagle, which preys on it in Scotland, in Switzerland, and in other lands.

The author tries to be fair to the grey squirrel, an unpopular immigrant from America, and she does not find it proved that its increase is the reason for the decrease of the red squirrel. The book is enriched by some excellent photographs and maps.

SETON GORDON 